\title{
Oral administration of leaf extracts to rumen liquid donor lambs modifies in vitro gas production of other tree leaves ${ }^{\text {in }}$
}

\author{
A.Z.M. Salem ${ }^{\mathrm{a}, \mathrm{b}, *}$ \\ ${ }^{a}$ Facultad de Medicina Veterinaria y Zootecnia, Universidad Autónoma del Estado de México, México \\ ${ }^{\mathrm{b}}$ Faculty of Agriculture (El-Shatby), Alexandria University, Egypt
}

\section{A R T I C L E I N F O}

\section{Keywords:}

Tree leaves

Gas production

Extract

Lambs

\begin{abstract}
A B S T R A C T
This study was conducted to determine if adaptation of lambs to ingestion of tree leaf extracts of Salix babylonica and Leucaena leucocephala can modify in vitro gas production of Celtis ehrenbergiana, Ficus trigonata, Fraxinus excelsior and Prunus domestica. Samples of leaves were collected in triplicate (i.e., three individual samples of each tree leaf). Rumen inoculum was collected from 8 growing lambs fed a total mixed ration ad libitum (control; $R C$ ). Incubations were repeated with the rumen fluid collected from another 8 growing lambs of the same breed fed the same ration, but fed a daily dose of $30 \mathrm{ml} / \mathrm{d}$ of $S$. babylonica and L. leucocephala extracts in a 1:1 (v:v) mixture (treatment; RX). Leaf samples were incubated with each rumen fluid (i.e., RC and RX inoculums) in 3 runs on different weeks. Data of each of the three runs within sample replicate were averaged and used as the mean value of each individual sample within tree species for statistical analysis in a 4 (tree species) $\times 2$ (rumen inoculum) factorial design. In vitro gas production was recorded at 2, 4, 6, 8, 10, $12,24,48$ and $72 \mathrm{~h}$ of incubation. After $72 \mathrm{~h}$, the incubation was stopped and supernatant $\mathrm{pH}$ was determined, and then filtered to determine apparent degraded substrate (ADS). Fermentation parameters, such as the $72 \mathrm{~h}$ partitioning factor $\left(\mathrm{PF}_{72}\right), 24 \mathrm{~h}$ gas yield $\left(\mathrm{GY}_{24}\right)$, in vitro organic matter digestibility (IVOMD), metabolizable energy (ME), short chain fatty acids concentration (SCFA), and microbial protein production (MP) were estimated. The crude protein content of the leaves ranged from 147 (F. trigonata) to 241 (C. ehrenbergiana) $\mathrm{g} / \mathrm{kg}$ dry matter. The lowest fiber fraction values was in $P$. domestica, while $F$. excelsior had the highest, and C. ehrenbergiana and F. trigonata were intermediate. Secondary metabolites (i.e., total phenolics, saponins, aqueous fraction) were lowest in $P$. domestica and highest in $F$. trigonata. Accumulated gas production was highest $(\mathrm{P}<0.05)$ in $F$. excelsior during the first $24 \mathrm{~h}$ of incubation. All fermentation parameters (i.e., ADS, SCFA, $\mathrm{GY}_{24}, \mathrm{PF}_{72}$, IVOMD, ME, MP) varied $(\mathrm{P}<0.01)$ among tree leaves. The ADS, SCFA and MP were highest $(\mathrm{P}<0.01)$ in F. excelsior, lowest $(\mathrm{P}<0.01)$ in $F$. trigonata, and intermediate in $P$. domestica and C. ehrenbergiana. Incubation of tree leaves with RX inoculum did not affect gas production in the first $6 \mathrm{~h}$, but it was lower $(\mathrm{P}<0.05)$ at $24-72 \mathrm{~h}$, except for $F$. trigonata. $C$. ehrenbergiana had the highest $(\mathrm{P}<0.05)$ potential gas production, but rate of gas production and the discrete lag time did
\end{abstract}

Abbreviations: ADS, apparently degraded substrate; ADFom, acid detergent fiber; CP, crude protein; DM, dry matter; EE, ether extract; GY 24 , gas yield at $24 \mathrm{~h}$ of incubation; IVOMD, in vitro organic matter digestibility; MP, microbial CP production; ME, metabolizable energy; NDFom, neutral detergent fiber; $\mathrm{PF}_{72}$, partitioning factor at $72 \mathrm{~h}$ of incubation; SCFA, short chain fatty acids.

is This paper is part of the special issue entitled: Plant Bioactive Compounds in Ruminant Agriculture - Impacts and Opportunities, Guest Edited by A.Z.M. Salem and S. López, and Editor for Animal Feed Science and Technology, P.H. Robinson.

* Tel.: +52 172229655 42; fax: +5217221806194.

E-mail address: asalem70@yahoo.com 
not differ among leaves. As incubation of tree leaves with RX inoculum lowered $(\mathrm{P}<0.05)$ all fermentation parameters, oral administrated extracts of $S$. babylonica and L. leucocephala did not seem to adapt the rumen microbial population to better utilize these tree leaves.

(c) 2012 Elsevier B.V. All rights reserved.

\section{Introduction}

Browse trees and shrubs can be used as feed supplements in areas with long dry periods or harsh environmental conditions, such as northern and central Mexico, because they provide forage for grazing ruminants throughout the year, and/or at specific critical periods of the year, particularly after herbage senescence when the quantity and quality of herbaceous species is limited. Browse trees and shrubs can be an important component of goat and sheep diets (Papachristou and Nastis, 1996; Salem et al., 2006), and play an important role in nutrition of grazing ruminants in areas where few, or no, alternative feeds are available (Meuret et al., 1990). However use of tree and shrub leaves by ruminants may be restricted by negative effects on digestion of their generally high levels of secondary metabolites (Salem, 2005; Salem et al., 2006, 2007) and/or by their impacts on rumen microorganisms (McSweeney et al., 2001).

Many factors modify activities of rumen microorganisms which relate to fermentation of browse tree species and shrubs. These include animal species (Salem, 2005), diet composition (Getachew et al., 2005), shrub composition (Salem et al., 2006, 2007) and feed additives (Gado et al., 2009, 2011; Jiménez-Peralta et al., 2011; Salem et al., 2011a, 2012). Administration of leaf extracts to ruminants as feed additives have modified in vitro ruminal fermentation of high concentrate diets in lambs fed a daily dose of Salix babylonica and Leucaena leucocephala extract (Jiménez-Peralta et al., 2011), and improved in vivo digestibility and average daily gain of lambs (Salem et al., 2011a). Some plant extracts have also improved animal growth and nutrient digestion (Mapiye et al., 2010; Salem et al., 2011a) due to positive impacts of their secondary metabolites on activity of ruminal microorganisms (Jiménez-Peralta et al., 2011; Xu et al., 2010) and/or increased amino acid flow to the duodenum (Mueller-Harvey, 2006), which can result in more muscle deposition and, consequently, heavier carcasses (Gleghorn et al., 2004) and improved meat quality (Mapiye et al., 2010).

The aim was to determine if adaptation of lambs to ingestion of a tree leaf extract rich in plant secondary metabolites can modify or change in vitro digestion of some tree species leaves rich in secondary metabolites.

\section{Materials and methods}

\subsection{Tree foliage species collection}

Samples of leaves of the four species (i.e., Celtis ehrenbergiana, Ficus trigonata, Fraxinus excelsior and Prunus domestica) were randomly and manually harvested from different parts of trees to obtain three individual samples of young and mature leaves from each tree species. Leaf samples were dried at $40^{\circ} \mathrm{C}$ for $72 \mathrm{~h}$ in a forced air oven to constant weight, ground in a hammer mill to pass a $1 \mathrm{~mm}$ sieve and stored in plastic bags for subsequent determination of chemical components, secondary metabolites and in vitro gas production.

\subsection{Animals as rumen inoculum donors}

Rumen inoculum was collected by stomach tube from 8 growing Katahdin $\times$ Pelibuey lambs with a live weight of $24 \pm 0.3 \mathrm{~kg}$ fed a total mixed ration (TMR) ad libitum based on soyabean meal, 220; alfalfa hay, 150; sorghum grain, 550; fishmeal, 35; mineral/vitamin premix, 25 and salt, 20 (g/kg dry matter (DM)) and used as the control inoculum (RC). Incubations were repeated with rumen inoculum collected from another 8 growing lambs of the same breed and fed the same TMR, but fed a daily $30 \mathrm{ml}$ dose of extracts of $S$. babylonica and $L$. leucocephala in a 1:1 (v:v) mixture (RX). The RC and RX lambs were fed ad libitum a TMR formulated to meet all of their nutrient requirements (NRC, 1985). Extracts were orally administered daily to RX lambs before the 8:00 h feeding. Fresh water was always available.

\subsection{Preparation of extracts for RX lambs}

Tree leaves of L. leucocephala and S. babylonica were collected randomly from several young and mature trees during summer. Leaves were fresh chopped into 1-2 cm lengths and immediately extracted at $1 \mathrm{~g}$ leaf $/ 8 \mathrm{ml}$ of solvent which contained $10 \mathrm{ml}$ methanol (99.8/100, analytical grade, Fermont ${ }^{\circledR}$, Monterrey, Mexico), $10 \mathrm{ml}$ ethanol (99/100, analytical grade, Fermont ${ }^{\circledR}$, Monterrey, Mexico) and $80 \mathrm{ml}$ of distilled water. Plant materials were individually soaked and incubated in solvent in a laboratory at room temperature $\left(\right.$ i.e., $25-30^{\circ} \mathrm{C}$ ) for $48-72 \mathrm{~h}$ in closed $20 \mathrm{~L}$ jars. After incubation, jars were heated at $30^{\circ} \mathrm{C}$ for $1 \mathrm{~h}$, and then immediately filtered and individual filtrates (extract) were collected. Extract was prepared weekly (stock volume of $2 \mathrm{~L}$ each) by mixing the S. babylonica and L. leucocephala extracts (500:500, v:v). This mixture was stored at $4{ }^{\circ} \mathrm{C}$ prior to daily oral administration to the lambs (Salem et al., 2011a). 


\subsection{In vitro incubations}

Rumen fluid of RC and RX inoculums of lambs was collected by stomach tube. Ruminal contents of each lamb were obtained immediately before the morning feeding, mixed and strained through 4 layers of cheesecloth into a flask with $\mathrm{O}_{2}$ free headspace. Samples $(1 \mathrm{~g})$ of each tree leaf species were weighed into $120 \mathrm{ml}$ serum bottles. After that, $10 \mathrm{ml}$ of particle-free ruminal fluid was added to each bottle and $40 \mathrm{ml}$ of the buffer solution of Goering and Van Soest (1970), with no trypticase added, was immediately added in a proportion 1:4 (v/v).

A total of 219 bottles ( 3 bottles of each triplicate sample within each of the 4 tree species in 3 runs on different weeks for each rumen inoculum (i.e., RC and RX) with 3 bottles as blanks (i.e., rumen fluid only), were incubated for $72 \mathrm{~h}$. Once all bottles were filled, they were immediately closed with rubber stoppers, shaken and placed in the incubator at $39{ }^{\circ} \mathrm{C}$. The volume of gas produced was recorded at 2, 4, 6, 8, 10, 12, 24, 48 and $72 \mathrm{~h}$ of inoculation using the reading pressure technique (RPT; DELTA OHM, Italy) of Theodorou et al. (1994). At the end of incubation (i.e., $72 \mathrm{~h}$ ), bottles were uncapped, pH was measured immediately with a pH meter (GLP 22, Crison Instruments, Barcelona, Spain), and fermentation was stopped by swirling the bottles in ice. Contents of each bottle were transferred as filtered fermentation residue for determination of apparently degraded substrate.

\subsection{Apparently degraded substrate}

At the end of the incubation (i.e., $72 \mathrm{~h}$ ), contents of each serum bottle were filtered through glass crucibles with a sintered filter (coarse porosity no. 1, pore size 100-160 $\mu \mathrm{m}$, Pyrex, Stone, UK) under vacuum. Fermentation residues were dried at $105^{\circ} \mathrm{C}$ overnight to estimate potential DM disappearance. Loss in weight after drying was the measure of undegradable DM. The DM degradability at $72 \mathrm{~h}$ of incubation (i.e., apparently degraded substrate, ADS; mg/g DM) was calculated as the difference between DM content of substrate and its undegradable DM.

\subsection{Chemical analyses and secondary metabolites}

Tree leaf samples were analyzed for DM (\#934.01), ash (\#942.05), N (\#954.01) and EE (\#920.39) according to AOAC (1997). The neutral detergent fiber (NDFom, Van Soest et al., 1991), acid detergent fiber (ADFom) and lignin(sa) (AOAC, 1997); \#973.18) analyses used an ANKOM200 Fibre Analyzer unit (ANKOM Technology Corporation, Macedon, NY, USA). NDFom was assayed without use of an alpha amylase but with sodium sulfite in the NDFom. Both NDFom and ADFom are expressed without residual ash.

Plant secondary metabolites were determined in the leaves from each tree species. Ten ml of extract was fractionated by funnel separation with a double volume of ethyl acetate $\left(99.7 / 100\right.$, analytical grade, Fermont ${ }^{\circledR}$, Monterrey, Mexico) to determine total phenolics by drying and quantifying the total phenolics layer in the funnel. After total phenolics separation, a double volume of n-butanol (99.9/100, analytical grade, Fermont ${ }^{\circledR}$, Monterrey, Mexico), was added to fractionate saponins (Makkar et al., 1998; Ahmed et al., 1990). The remaining solution was considered to be the aqueous fraction which has other secondary metabolites such as lectins and polypeptides (Cowan, 1999).

\subsection{Calculations}

To estimate kinetic parameters of gas production, gas production results ( $\mathrm{ml} / \mathrm{g}$ DM) were fitted using the NLIN option of SAS (2002) to the France et al. (2000) model as:

$$
A=b \times\left(1-e^{-c(t-L)}\right)
$$

where $A$ is the volume of gas production at time $t ; b$ the asymptotic gas production ( $\mathrm{ml} / \mathrm{g}$ DM); $c$ is the rate of gas production (/h), and $L(\mathrm{~h})$ is the discrete lag time prior to gas production.

Metabolizable energy (ME, MJ/kg DM) and in vitro OM digestibility (IVOMD, g/kg OM) were estimated according to Menke et al. (1979) as:

$$
\begin{aligned}
& \mathrm{ME}=2.20+0.136 \mathrm{GP}+0.0057 \mathrm{CP}(\mathrm{g} / \mathrm{kg} \mathrm{DM}) \\
& \mathrm{IVOMD}=148.8+8.89 \mathrm{GP}+0.45 \mathrm{CP}(\mathrm{g} / \mathrm{kg} \mathrm{DM})+0.65 \mathrm{ash}(\mathrm{g} / \mathrm{kg} \mathrm{DM})
\end{aligned}
$$

where GP is net gas production in $\mathrm{ml}$ from $200 \mathrm{mg}$ dry sample after $24 \mathrm{~h}$ of incubation.

The partitioning factor at $72 \mathrm{~h}$ of incubation $\left(\mathrm{PF}_{72}\right.$; a measure of fermentation efficiency) was calculated as the ratio of apparent degraded substrate in vitro (ADS, $\mathrm{mg}$ ) to the volume of gas (ml) produced at $72 \mathrm{~h}$ (i.e., ADS/total gas production $\left(\mathrm{GP}_{72}\right)$ ) according to Blümmel et al. (1997). Gas yields $\left(\mathrm{GY}_{24}\right)$ were calculated as the volume of gas (ml gas/g DM) produced after $24 \mathrm{~h}$ of incubation divided by ADS ( $\mathrm{g}$ ) as:

$$
\text { Gas yields }\left(\mathrm{GY}_{24}\right)=\mathrm{ml} \text { gas } / \mathrm{g} \mathrm{DM} / \mathrm{g} \text { ADS }
$$


Table 1

Chemical composition and secondary metabolites levels ( $\mathrm{g} / \mathrm{kg} \mathrm{DM})$ of the tree leaf species.

\begin{tabular}{|c|c|c|c|c|c|}
\hline & \multicolumn{4}{|l|}{ Species } & \multirow[t]{2}{*}{ SEM } \\
\hline & C. ehrenbergiana & F. trigonata & F. excelsior & P. domestica & \\
\hline Organic matter & $891.3^{d}$ & $933.7^{c}$ & $996.4^{\mathrm{a}}$ & $969.0^{\mathrm{b}}$ & 2.51 \\
\hline Crude protein & $241.4^{\mathrm{a}}$ & $146.5^{\mathrm{d}}$ & $174.1^{\mathrm{c}}$ & $207.3^{\mathrm{b}}$ & 4.55 \\
\hline Ether extract & 11.6 & 12.4 & 12.6 & 12.3 & 0.30 \\
\hline Neutral detergent fiber(om) & $344.5^{\mathrm{b}}$ & $318.0^{\mathrm{b}}$ & $408.3^{a}$ & $199.3^{c}$ & 8.36 \\
\hline Acid detergent fiber(om) & $159.8^{c}$ & $196.7^{\mathrm{b}}$ & $221.5^{\mathrm{a}}$ & $138.4^{\mathrm{d}}$ & 3.71 \\
\hline $\operatorname{Lignin}(\mathrm{sa})$ & $91.5^{\mathrm{b}}$ & $131.2^{\mathrm{ab}}$ & $142.1^{\mathrm{a}}$ & $82.4^{\mathrm{b}}$ & 3.99 \\
\hline Total phenolics & $37.3^{c}$ & $65.6^{\mathrm{a}}$ & $58.9^{\mathrm{b}}$ & $7.6^{\mathrm{d}}$ & 0.42 \\
\hline Saponins & $33.2^{\mathrm{a}}$ & $20.4^{b}$ & $12.4^{\mathrm{c}}$ & $13.3^{\mathrm{c}}$ & 0.87 \\
\hline Aqueous fraction ${ }^{\mathrm{a}}$ & $156.5^{\mathrm{a}}$ & $96.5^{c}$ & $116.8^{\mathrm{cb}}$ & $135.2^{\mathrm{b}}$ & 5.56 \\
\hline
\end{tabular}

a,b,c,d Different superscripts following means in the same row indicate differences at $\mathrm{P}<0.05$.

a Cowan (1999).

Short chain fatty acids concentration (SCFA) was calculated according to Getachew et al. (2002) as:

$$
\mathrm{SCFA}(\mathrm{mmol} / 200 \mathrm{mg} \mathrm{DM})=0.0222 \mathrm{GP}-0.00425
$$

where GP is the $24 \mathrm{~h}$ net gas production ( $\mathrm{ml} / 200 \mathrm{mg} \mathrm{DM})$.

Microbial biomass production (MP) was calculated according to Blümmel et al. (1997) as:

$$
\mathrm{MP}(\mathrm{mg} / \mathrm{g} \mathrm{DM})=\mathrm{mg} \text { ADS }-(\mathrm{ml} \text { gas } \times 2.2 \mathrm{mg} / \mathrm{ml})
$$

where $2.2 \mathrm{mg} / \mathrm{ml}$ is a stoichiometric factor which expresses $\mathrm{mg}$ of $\mathrm{C}, \mathrm{H}$ and $\mathrm{O}$ required for the SCFA gas associated with production of one $\mathrm{ml}$ of gas (Blümmel et al., 1997).

\subsection{Statistical analyses}

Data of in vitro ruminal gas production and fermentation parameters were analyzed as a $4 \times 2$ factorial experiment (i.e., 4 tree leave species (random effect) and 2 rumen inocula (fixed effect)) according to a randomized block design using the PROC MIXED procedure of SAS (2002). Data of each one of the 3 runs within the same sample were averaged. Mean values of each individual sample within each species (3 samples of each) were the experimental unit (Udén et al., 2011), and the statistical model was:

$$
Y_{i j k}=\mu+S_{i}+R_{j}+S_{i} * R_{j}+\varepsilon_{i j k}
$$

where $Y_{i j k}$ represents every observation of the $i$ th browse species when incubated in the $j$ th rumen inoculum (extract), $S_{i}$ ( $i=1-4)$ the browse tree species effect, $R_{j}\left(j=\right.$ control (RC) or extract (RX) lambs) is the rumen inoculum effect, $S_{i}{ }^{*} R_{j}$ is the interaction between tree species and rumen inoculum, and $\varepsilon_{i j k}$ is the experimental error. Tukey's test was used for the multiple comparisons among mean values for the four plant species.

\section{Results}

The CP content of the leaves ranged from 147 (F. trigonata) to 241 (C. ehrenbergiana) g/kg DM (Table 1). Fiber levels (i.e., NDFom, ADFom, lignin(sa)) were lowest in P. domestica, F. excelsior had the highest, and C. ehrenbergiana and F. trigonata were intermediate. Total phenolics were lower in $P$. domestica and higher in $F$. trigonata, while saponins were lower in $P$. domestica and F. excelsior, whereas they were highest in C. ehrenbergiana. Aqueous fraction was lowest in F. trigonata had the lowest and $C$. ehrenbergiana had the highest.

Tree species $\times$ rumen inoculum interactions $(\mathrm{P}<0.05)$ occurred for gas production $(\mathrm{ml} / \mathrm{g} \mathrm{DM})$ at all incubation times of measures (Table 2). Accumulated gas production was highest $(\mathrm{P}<0.05)$ in F. excelsior during the first $24 \mathrm{~h}$ of incubation $(i . e$., 6 and $24 \mathrm{~h})$. At $48 \mathrm{~h}, \mathrm{P}$. domestica had the highest $(\mathrm{P}<0.05)$ values, whereas at $72 \mathrm{~h}$ C. ehrenbergiana had the highest $(\mathrm{P}<0.05)$ values. Gas production of leaf species was not affected during the first $6 \mathrm{~h}$ of incubation in all tree species with $\mathrm{RX}$ inoculum, while it was decreased $(\mathrm{P}=0.016)$ after $12 \mathrm{~h}$ only in $F$. excelsior and $P$. domestica. From 24 to $72 \mathrm{~h}$ of incubation, gas production was lower $(\mathrm{P}<0.05)$ for all leaf species with RX inoculum, except $F$. trigonata. Highest potential gas production $(i . e$., fraction $b$ ) was in $C$. ehrenbergiana had the highest $(\mathrm{P}<0.05)$, but the rate of gas production (i.e., $c)$ and discrete time lag $(i . e ., L)$ did not differ among leaves. Incubation of tree leave species with RX inoculum decreased $(\mathrm{P}<0.05)$ fraction $b$ in all leaves, except $F$. trigonata, without impacts on $c$, and $L$, overall (Table 2 ).

All fermentation parameters (i.e., ADS, SCFA, $\mathrm{GY}_{24}, \mathrm{PF}_{72}$, IVOMD, ME and MP) varied ( $<<0.01$ ) among tree leaves. The ADS, SCFA and MP were highest $(\mathrm{P}<0.001)$ in F. excelsior, lowest $(\mathrm{P}<0.001)$ in $F$. trigonata, and intermediate in $P$. domestica and $C$. ehrenbergiana. Incubation of tree species with $\mathrm{RX}$ inoculum decreased $(\mathrm{P}<0.05)$ all the fermentation parameters, except $\mathrm{pH}$ (Table 3). 
Table 2

In vitro gas production parameters and gas volume accumulated after different hour of incubation of some tree leaf species in rumen liquor of control (RC) or extract administrated (RX) lambs.

\begin{tabular}{|c|c|c|c|c|c|c|c|c|c|c|c|c|}
\hline \multirow{2}{*}{$\begin{array}{l}\text { Species (S) } \\
\text { Rumen liquor (R) }\end{array}$} & \multicolumn{2}{|c|}{ C. ehrenbergiana } & \multicolumn{2}{|c|}{ F. trigonata } & \multicolumn{2}{|c|}{ F. excelsior } & \multicolumn{2}{|c|}{ P. domestica } & \multirow[t]{2}{*}{ SEM } & \multicolumn{3}{|l|}{$\mathrm{P}$} \\
\hline & $\mathrm{RC}$ & $\mathrm{RX}$ & $\mathrm{RC}$ & $\mathrm{RX}$ & $\mathrm{RC}$ & $\mathrm{RX}$ & $\mathrm{RC}$ & $\mathrm{RX}$ & & $\mathrm{S}$ & $\mathrm{R}$ & $\mathrm{S} \times \mathrm{R}$ \\
\hline \multicolumn{13}{|c|}{ In vitro gas production (ml/g DM) } \\
\hline Gas6 & $30.8^{\mathrm{b}}$ & $33.8^{\mathrm{a}}$ & $37.8^{\mathrm{b}}$ & $40.4^{\mathrm{a}}$ & 44.9 & 44.8 & $48.7^{\mathrm{a}}$ & $27.5^{\mathrm{b}}$ & 2.43 & 0.02 & 0.14 & 0.01 \\
\hline Gas24 & $97.1^{\mathrm{a}}$ & $81.0^{\mathrm{b}}$ & 80.6 & 85.4 & $107.4^{\mathrm{a}}$ & $89.7^{b}$ & $127.7^{\mathrm{a}}$ & $67.2^{\mathrm{b}}$ & 4.77 & 0.11 & 0.02 & 0.01 \\
\hline Gas48 & $146.2^{\mathrm{a}}$ & $97.2^{\mathrm{b}}$ & 90.2 & 95.6 & $128.7^{\mathrm{a}}$ & $97.7^{\mathrm{b}}$ & $163.3^{\mathrm{a}}$ & $84.1^{\mathrm{b}}$ & 5.36 & 0.01 & $<0.01$ & 0.01 \\
\hline Gas72 & $171.1^{\mathrm{a}}$ & $100.6^{\mathrm{b}}$ & 91.3 & 96.9 & $133.2^{\mathrm{a}}$ & $98.4^{\mathrm{b}}$ & $173.3^{\mathrm{a}}$ & $89.8^{\mathrm{b}}$ & 5.56 & 0.01 & $<0.01$ & 0.01 \\
\hline \multicolumn{13}{|c|}{ Gas production parameters ${ }^{\mathrm{a}}$} \\
\hline$b(\mathrm{ml} / \mathrm{g} \mathrm{DM})$ & $196.8^{a}$ & $101.7^{\mathrm{b}}$ & 91.5 & 97.1 & $134.4^{\mathrm{a}}$ & $98.5^{\mathrm{b}}$ & $177.2^{\mathrm{a}}$ & $93.8^{\mathrm{b}}$ & 5.58 & $<0.01$ & $<0.01$ & $<0.01$ \\
\hline$c(/ \mathrm{h})$ & 0.029 & 0.070 & 0.089 & 0.093 & 0.068 & 0.102 & 0.053 & 0.059 & 0.0061 & 0.01 & 0.01 & 0.11 \\
\hline$L(/ \mathrm{h})$ & 1.47 & 1.98 & 1.69 & 2.48 & 1.75 & 2.74 & 1.60 & 1.81 & 0.154 & 0.06 & 0.01 & 0.33 \\
\hline
\end{tabular}

a,b Different superscripts following means within tree leaf species in the same row indicate differences at $\mathrm{P}<0.05$.

${ }^{a} b$ is the asymptotic gas production ( $\left.\mathrm{ml} / \mathrm{g} \mathrm{DM}\right) ; c$ is the rate of gas production $(/ \mathrm{h})$; $L$ is the initial delay before gas production begins (h).

\section{Discussion}

\subsection{Effect of tree species}

The variation in the chemical composition of our tree species has occurred in other studies with shrubs and tree species (Salem et al., 2007; Mbugua et al., 2008). The high CP content of $P$. domestica and F. excelsior was similar to those of other high quality shrubby forages such as Calycotum villosa (Gasmi-Boubaker et al., 2005). While the CP content per se should not be the sole criteria of judging the relative importance of a particular feedstuff. The difference in CP content among species may be due to inherent characteristics of each species related to their ability to extract and accumulate nutrients from the soil, as well as atmospheric N. Other factors causing variation in the chemical composition of browse forages include planting location, plant part, age of leaf and season. With regard to geographical location, some authors have reported that browse plants in arid zones have higher $\mathrm{N}$ than plants of the same species in humid zones (Rittner and Reed, 1992; Salem, 2005).

Differences among browse trees and shrubs in NDFom and ADFom contents are consistent with Khanal and Subba (2001) and Salem et al. (2007). In our study, the ADF/NDF ratio was highest for P. domestica (mean: 0.69), lowest for C. ehrenbergiana (0.46) and F. trigonata (0.53) and F. excelsior (0.54) had the intermediate. For all samples, the ADFom fraction is a large proportion of NDFom, suggesting a high content of cellulose and lignin, but lower levels of hemicellulose (Salem et al., 2007).

Gas production parameters suggested differences in nutritional value which were generally closely related to chemical composition (Kamalak et al., 2005; Salem, 2005; Salem et al., 2007). The high gas production during the first 24h in $P$. domestica and $F$. excelsior suggests a higher extent of fermentation in the first $24 \mathrm{~h}$ of fermentation (Gas24) versus the other leaves, especially F. trigonata (Table 2). Differences in gas production among leaves could be due to the proportion, and nature, of their fiber (Rubanza et al., 2003). Indeed the higher fiber levels, as well as high levels of secondary metabolites in F. trigonata (Salem et al., 2006, 2007), are almost certainly responsible for its reduced gas production versus the other leaves. However, differences in degradability among leaves could also be due to the extent of lignification of NDFom (Van Soest, 1994; Fonesca et al., 1998), and/or negatively correlated with both NDFom and lignin(sa) (Salem et al., 2007).

The low gas production of $F$. trigonata could also be due to its NDFom being bound by polyphenolics (Ndlovu and Nherera, 1997). Higher in vitro gas production from $P$. domestica could be due to its lower secondary metabolite levels (Salem et al., 2006, 2007), although some variation among leaves could be due to genotypic characteristics and relative to the type of

Table 3

In vitro rumen fermentation profile ${ }^{\mathrm{a}}$ of some tree leave species incubated in rumen liquor from control (RC) or extract administrated (RX) lambs.

\begin{tabular}{|c|c|c|c|c|c|c|c|c|c|c|c|c|}
\hline \multirow{2}{*}{$\begin{array}{l}\text { Species }(S) \\
\text { Rumen liquor }(R)\end{array}$} & \multicolumn{2}{|c|}{ C. ehrenbergiana } & \multicolumn{2}{|c|}{ F. trigonata } & \multicolumn{2}{|c|}{ F. excelsior } & \multicolumn{2}{|c|}{ P. domestica } & \multirow[t]{2}{*}{ SEM } & \multicolumn{3}{|l|}{$\mathrm{P}$} \\
\hline & $\mathrm{RC}$ & $\mathrm{RX}$ & $\mathrm{RC}$ & $\mathrm{RX}$ & $\mathrm{RC}$ & $\mathrm{RX}$ & $\mathrm{RC}$ & $\mathrm{RX}$ & & $\mathrm{S}$ & $\mathrm{R}$ & $\mathrm{S} \times \mathrm{R}$ \\
\hline $\mathrm{pH}$ & 7.04 & 7.04 & 7.11 & 7.11 & 6.95 & 6.95 & 7.05 & 7.05 & 0.009 & 0.01 & 1.00 & 1.00 \\
\hline ADS & 671 & 606 & 604 & 624 & $713 a$ & $641^{\mathrm{b}}$ & $796^{a}$ & $550^{\mathrm{b}}$ & 19.4 & 0.11 & 0.02 & 0.01 \\
\hline SCFA & $2.13^{\mathrm{a}}$ & $1.78^{\mathrm{b}}$ & 1.77 & 1.88 & $2.36^{\mathrm{a}}$ & $1.97^{\mathrm{b}}$ & $2.81^{\mathrm{a}}$ & $1.47^{\mathrm{d}}$ & 0.106 & 0.11 & 0.01 & 0.01 \\
\hline $\mathrm{GY}_{24}$ & 144.6 & 133.4 & 133.4 & 135.7 & $150.6^{\mathrm{a}}$ & $139.8^{\mathrm{b}}$ & $160.5^{\mathrm{a}}$ & $120.4^{b}$ & 3.75 & 0.29 & 0.01 & 0.01 \\
\hline $\mathrm{PF}_{72}$ & $6.9^{b}$ & $7.5^{\mathrm{a}}$ & 7.5 & 7.4 & 6.7 & $7.2 \mathrm{~d}$ & $6.2^{\mathrm{b}}$ & $8.4^{\mathrm{a}}$ & 0.23 & 0.38 & 0.03 & 0.02 \\
\hline IVOMD & $43.7^{\mathrm{a}}$ & $40.9^{\mathrm{b}}$ & 36.2 & 37.1 & $41.8^{\mathrm{a}}$ & $38.7^{\mathrm{b}}$ & $47.1^{\mathrm{a}}$ & $36.4^{\mathrm{b}}$ & 0.85 & 0.01 & 0.02 & 0.01 \\
\hline $\mathrm{ME}$ & $6.2^{\mathrm{a}}$ & $5.8^{\mathrm{b}}$ & $5.2^{\mathrm{b}}$ & $5.4^{\mathrm{a}}$ & $6.1^{\mathrm{a}}$ & $5.6^{\mathrm{b}}$ & $6.9^{\mathrm{a}}$ & $5.2^{\mathrm{b}}$ & 0.13 & 0.01 & 0.02 & 0.01 \\
\hline $\mathrm{MP}$ & $457.6^{\mathrm{a}}$ & $427.5^{b}$ & $426.7^{b}$ & $435.7^{a}$ & $476.9^{a}$ & $443.6^{\mathrm{b}}$ & $514.7^{a}$ & $401.7^{b}$ & 8.92 & 0.11 & 0.02 & 0.01 \\
\hline
\end{tabular}

a,b Different superscripts following means within tree leaf species in the same row indicate differences at $\mathrm{P}<0.05$.

a ADS is the apparent degraded substrate (mg/g DM); SCFA is the short chain fatty acids (mmol/g DM); GY 24 is the gas yield at $24 \mathrm{~h}$ ( $\mathrm{ml}$ gas/g ADS); $\mathrm{PF} 72$ is the partitioning factor at $72 \mathrm{~h}$ of incubation ( $\mathrm{mg}$ ADS: $\mathrm{ml}$ gas); IVOMD is the in vitro organic matter digestibility ( $\mathrm{g} / \mathrm{kg}$ MS); ME is the metabolizable energy (MJ/kg DM); MP is the and microbial protein production (mg/g DM). 
secondary metabolite activity on digestibility (Muetzel and Becker, 2006; Salem et al., 2006, 2007). This suppressing effect probably resulted from a reduction in microbial attachment to feed particles (McAllister et al., 1994) and inhibition of microbial growth and enzyme activity (McSweeney et al., 2001). Salem et al. (2010) found that L. plantarum was more susceptible than E. faecium to secondary metabolites in the medium, and had a higher response to polyethyleneglycol (PEG) addition, which reduced toxicity in both bacterial strains. Lactic acid bacteria would be affected to a different extent by secondary metabolites reaching the small intestine, whereas PEG may neutralize inhibitory effects of secondary metabolites on these bacterial species.

Increased IVOMD, ME and ruminal fermentation parameters of $P$. domestica reflect its higher fermentation and lower secondary compound levels. In contrast, lower values in $F$. trigonata and $F$. excelsior represent less fermentation and higher secondary compound levels (Salem et al., 2006, 2007). Similar results were reported by Peng et al. (2005) who showed reduced IVOMD of Lucerne chaff incubated with secondary compounds extracted from L. sativus, and suggested that oxalyldiaminobutyric acid, rather than phenolics, were responsible for inhibition of cellulolytic bacteria. However digestibility of tree leaves was adversely affected by secondary metabolites in vitro (Peng et al., 2005) and in vivo (Salem et al., 2006, 2007).

The lowest microbial protein production (MP) occurred in leaves with higher levels of secondary metabolites (i.e., $F$. trigonata) where lower gas production suggests a role of phenolics as an anti-methanogen which stimulates growth of propionate producing bacteria. Lower methane production, with higher propionate, is consistent with higher MP (McCrabb et al., 1997).

\subsection{Effect of ruminal liquor inoculum}

Reduced ruminal fermentation activities of tree species in RX rumen fluid probably due to the negative impacts of a chemical, possibly formed by mixing of the two extract species which were orally administered to the lambs (i.e., RX lambs). Salem et al. (2011b) detected 60 chemical constitutes formed by a mixture of an S. babylonica extract with an L. leucocephala extract. The main compounds in the extract mixture were 9,12,15-octadecatrienoic acid-ethyl ester with concentration of $294 \mathrm{mg} / \mathrm{g}$ followed by 9,12-octadecadienoic acid-methyl ester $(112 \mathrm{mg} / \mathrm{g})$, and hexadecanoic acid-methyl ester a saturated fatty acid, with a concentration of $90 \mathrm{mg} / \mathrm{g}$. Hexacontanoic acid $(21 \mathrm{mg} / \mathrm{g}), 5,8,11,14,17$-eicosapentaenoic acid-methyl ester $(20 \mathrm{mg} / \mathrm{g})$ and octadecanoic acid-16-methyl-methyl ester $(10 \mathrm{mg} / \mathrm{g})$ were the major fatty acids. However, there was $129 \mathrm{mg} / \mathrm{g}$ of 1,3-dioxane, 4-(hexadecyloxy)-2-pentadecyl and the aliphatic hydrocarbon in the tritetracontane form was $32 \mathrm{mg} / \mathrm{g}$ (Salem et al., 2011b). These chemicals were very different from those in the individual extracts and could negatively affect ruminal microbes. Jiménez-Peralta et al. (2011) used the same lambs as used in our experiment as rumen fluid donors to study impacts of type of ruminal liquor (i.e., RC or RX) on in vitro fermentation of a high concentrate diet fed to the same lambs with or without different levels of tree extracts, and found that mixing extracts of S. babylonica and L. leucocephala reduced gas production and ruminal fermentation of the high concentrate diet, suggesting formation of a hydroxyl radical in a reaction with the extract mixture which reduced ruminal microbial activities and their ability to degrade deoxyribose (Jirovetz et al., 2007). Salem et al. (2011a) studied impacts of the same individual extracts of S. babylonica and $L$. leucocephala or their mixture $(1: 1, \mathrm{v} / \mathrm{v})$ on average daily gain and diet digestibility of the same lambs as used in our study and found that mixing of the two extracts $24 \mathrm{~h}$ before oral administration reduced average daily gain and nutrient digestibility compared to the individual extracts, but without differences from the control diet (without extract).

Another explanation for the reduced ruminal fermentation activities of tree species in RX rumen fluid could be due to the lambs which received the combined extract for $63 \mathrm{~d}$ not producing salivary proteins to protect tree leaves from the negative impacts of secondary metabolites, and/or that a feedback control mechanism may not have evolved or may have been lost. This effect could be due to changes in parotid saliva composition as, for instance, K secretion was lower in RX lambs (Salem, 2002). Based on our results, lambs administrated the extract mixture would not secrete salivary proteins, and/or the activity of their saliva to deactivate tannins would be negligible. Our results are consistent with Ammar et al. (2011), who assessed the nutritional influence of pre-incubation in saliva collected from sheep fed alfalfa hay with $50 \mathrm{~g}$ quebracho/kg DM for $60 \mathrm{~d}$ on in vitro fermentation of some tanniniferous shrubs in batch cultures of mixed ruminal microorganisms. The authors did not find differences between incubation of shrub species in the saliva between the control and quebracho sheep in any of the variables studied based on gas production. Results reported in a previous study (Ammar et al., 2009) provided evidence that microbial populations in the rumen of sheep fed a diet supplemented with quebracho tannins may evolve mechanisms of adaptations to counteract condensed tannins in browse species, and a symbiotic relationship between the host animal and the tannin-resistant bacteria may be established (Sasaki et al., 2005). These changes in ruminal populations would enable ruminants to overcome the antinutritional effects of tanniferous species. It appears that the major mechanism to detoxify tannins depends upon changes in the ruminal microbial population to offset the activity of phenolic compounds (Ammar et al., 2009). This was an unexpected finding because it precludes the probability that any defensive mechanism induced by adaptation to regular ingestion of tannins has been developed (Makkar, 2003), thereby changing the salivary protein profile (Costa et al., 2008).

\section{Conclusions}

F. excelsior and $P$. domestica leaves had the highest in vitro fermentation among four tree species with lower secondary metabolite concentrations. Incubations of tree species with rumen inoculum of lambs fed plant extracts for $60 \mathrm{~d}$ reduced 
ruminal fermentation of all tree species. It is clear that the orally administrated extract mixture could modify rumen gas production and fermentation of browse trees specie, which may affect their utilization by growing lambs.

\section{Acknowledgments}

I wish to acknowledge the financial support from SEP, Mexico, Project PRPMEP 103.5/09/4195.

\section{References}

Ahmed, V.U., Perveen, S., Bano, S., 1990. Saponin from the leaves of Guaiacum officinale. Phytochemistry 29, 3287-3290.

Ammar, H., López, S., Salem, A.Z.M., Bodas, R., González, J.S., 2011. Effect of saliva from sheep that have ingested quebracho tannins on the in vitro rumen fermentation activity to digest tannin-containing shrubs. Anim. Feed Sci. Tech. 163, 77-83.

Ammar, H., López, S., Kamoun, M., Bodas, R., Giraldez, F.J., González, J.S., 2009. Feeding quebracho tannins to sheep enhances rumen fermentative activity to degrade browse shrubs. Anim. Feed Sci. Tech. 149, 1-15.

AOAC - Association of Official Analytical Chemists, 1997. Official Methods of Analysis, 16th ed. AOAC, Arlington, VA, USA.

Blümmel, M., Steingss, H., Becker, K., 1997. The relationship between in vitro gas production, in vitro microbial biomass yield and ${ }^{15} \mathrm{~N}$ incorporation and its implications for the prediction of voluntary feed intake of roughages. Br. J. Nutr. 77, 911-921.

Costa, G., Lamy, E., Silva, F.C., Andersen, J., Baptista, E.S., Coelho, A.V., 2008. Salivary amylase induction by tannin-enriched diets as a possible countermeasure against tannins. J. Chem. Ecol. 34, 376-387.

Cowan, M.M., 1999. Plant products as antimicrobial agents. Clin. Microbiol. Rev. 12, 564-582.

Fonesca, A.J.M., Dias-da-Solva, A.A., Ørskov, E.R., 1998. In sacco degradation characteristics as predictor of digestibility and voluntary intake of roughages by manure ewes. Anim. Feed Sci. Tech. 72, 205-219.

France, J., Dijkstra, J., Dhanoa, M.S., Lopez, S., Bannink, A., 2000. Estimating the extent of degradation of ruminant feeds from a description of their gas production profiles observed in vitro: derivation of models and other mathematical considerations. Br. J. Nutr. 83, 143-150.

Gado, H.M., Salem, A.Z.M., Odongo, N.E., Borhami, B.E., 2011. Effect of exogenous enzymes ensiled with orange pulp on digestion, blood metabolites and growth performance in lambs. Anim. Feed Sci. Tech. 165, 131-136.

Gado, H.M., Salem, A.Z.M., Robinson, P.H., Hassan, M., 2009. Influence of exogenous enzymes on nutrient digestibility, extent of ruminal fermentation as well as milk production and composition in dairy cows. Anim. Feed Sci. Tech. 154 (1-2), 36-46.

Gasmi-Boubaker, A., Kayouli, C., Buldgen, A., 2005. In vitro gas production and its relationship to in situ disappearance and chemical composition of some Mediterranean browse species. Anim. Feed Sci. Tech. 123-124, 303-311.

Getachew, G., Makkar, H.P.S., Becker, K., 2002. Tropical browses: contents of phenolic compounds, in vitro gas production and stoichiometric relationship between short chain fatty acid and in vitro gas production. J. Agric. Sci. 139, 341-352.

Getachew, G., Robinson, P.H., DePeters, E.J., Taylor, S.J., Gisi, D.D., Higginbotham, G.E., Riordan, T.J., 2005. Methane production from commercial dairy rations estimated using an in vitro gas technique. Anim. Feed Sci. Tech. 123-124, 391-402.

Gleghorn, J.F., Elam, N.A., Galyean, M.L., Duff, G.C., Cole, N.A., Rivera, J.D., 2004. Effects of dietary crude protein level and degradability on performance and carcass characteristics of growing-finishing beef steers. J. Anim. Sci. 82, 2705-2717.

Goering, M.K., Van Soest, P.J., 1970. Forage fiber analysis (apparatus, reagents, procedures and some applications). In: Agriculture Handbook, No. 379. Agricultural Research Service, USDA, Washington, DC, USA.

Jiménez-Peralta, F.S., Salem, A.Z.M., Mejia-Hernández, P., González-Ronquillo, M., Albarrán-Portillo, B., Rojo-Rubio, R., Tinoco-Jaramillo, J.L., 2011. Influence of individual and mixed extracts of two tree species on in vitro gas production kinetics of high-concentrate diet fed to growing lambs. Livest. Sci. 136, 192-200.

Jirovetz, L., Buchbauer, G., Stoilova, I., Krastanov, A., Stoyanova, A., Schmidt, E., 2007. Spice plants: chemical composition and antioxidant properties of Pimenta Lindl. Essential oils, part 1: Pimenta dioica (L.) Merr. leaf oil from Jamaica. Nutrition 31, 55-62.

Kamalak, A., Canbolat, O., Gurbuz, Y., Ozay, O., Ozkose, E., 2005. Chemical composition and its relationship to in vitro gas production of several tannin containing tree and shrubs leaves. Asian-Aust. J. Anim. Sci. 18, 203-208.

Khanal, R.C., Subba, D.B., 2001. Nutritional evaluation of leaves from some major fodder trees cultivated in the hills of Nepal. Anim. Feed Sci. Tech. 92, $17-32$.

Makkar, H.P.S., 2003. Effects and fate of tannins in ruminant animals, adaptation to tannins, and strategies to overcome detrimental effects of feeding tannin-rich feeds. Small Rumin. Res. 49, 241-256.

Makkar, H.P.S., Sen, S., Blummel, M., Becker, K., 1998. Effects of fractions containing saponins from Yucca schidigera, Quillaja saponaria and Acacia auriculoformis on rumen fermentation. J. Agric. Food Chem. 46, 4324-4328.

Mapiye, C., Chimonyo, M., Dzama, K., Strydom, P.E., Muchenje, V., 2010. Meat quality attributes of Nguni steers supplemented with Acacia karroo leaf-meal. Meat Sci. 8, 621-627.

Mbugua, D.M., Kiruiro, E.M., Pell, A.N., 2008. In vitro fermentation of intact and fractionated tropical herbaceous and tree legumes containing tannins and alkaloids. Anim. Feed Sci. Tech. 146, 1-20.

McAllister, T.A., Bae, H.D., Jones, G.A., Cheng, K.J., 1994. Microbial attachment and feed digestion in the rumen. J. Anim. Sci. 72, 3004-3018.

McCrabb, G.J., Berger, K.T., Manger, T., May, C., Hunter, R.A., 1997. Inhibition methane production in Brahman cattle by dietary supplementation with a novel compound and the effects on growth. Aust. J. Agric. Res. 48, 323-329.

McSweeney, C.S., Palmer, B., McNeill, D.M., Krause, D.O., 2001. Microbial interactions with tannins: nutritional consequences for ruminants. Anim. Feed Sci. Tech. 91, 83-93.

Menke, K.H., Raab, L., Salewski, A., Steingass, H., Fritz, D., Schneider, W., 1979. The estimation of the digestibility and metabolizable energy content of ruminant feedstuffs from the gas production when they are incubated with rumen liquor in vitro. J. Agric. Sci. (Camb.) 92, 217-222.

Meuret, M., Boza, J., Narjisse, N., Nastis, A., 1990. Evaluation and utilization of rangeland feeds by goats. In: Morand-Fehr, P. (Ed.), Goat Nutrition. PUDOC, Wageningen, The Netherlands, pp. 161-170.

Mueller-Harvey, I., 2006. Unravelling the conundrum of tannins in animal nutrition and health. J. Sci. Food Agric. 86, 2010-2037.

Muetzel, S., Becker, K., 2006. Extractability and biological activity of tannins from various tree leaves determined by chemical and biological assays as affected by drying procedure. Anim. Feed Sci. Tech. 125, 139-149.

Ndlovu, L.R., Nherera, F.V., 1997. Chemical composition and relationship to in vitro gas production of Zimbabwean browsable indigenous tree species. Anim. Feed Sci. Tech. 69, 121-129.

NRC, 1985. Nutrient Requirements of Domestic Animals. National Research Council, Washington, DC, USA.

Papachristou, T.G., Nastis, A.S., 1996. Influence of deciduous broadleaved woody species in goat nutrition during the dry season in Northern Greece. Small Rumin. Res. 20, 15-22.

Peng, H., Revell, D., McSweeney, C.S., Brooker, J.D., 2005. Effect of different non-protein amino acids on in vitro dry matter digestibility of Lucerne chaff. Anim. Feed Sci. Tech. 121, 139-146.

Rittner, U., Reed, J.D., 1992. Phenolics and in vitro degradability of protein and fiber in West African browse. J. Sci. Food Agric. 58, 21-28.

Rubanza, C.D.K., Shem, M.N., Otsyina, R., Ichinohe, T., Fujihara, T., 2003. Nutritive evaluation of some browse tree legume foliages native to semi-arid area in western Tanzania. Asian Aust. J. Anim. Sci. 16, 1429-1437. 
Salem, A.Z.M., 2002. Parotid saliva production and composition, feeding behavior, rumen fermentation, digestibility, and plasmatic parameters in sheep and goats: evolution of the response to the condensed tannins of quebracho in the diet. Ph.D. Thesis. University of Leon, Leon, Spain.

Salem, A.Z.M., 2005. Impact of season of harvest on in vitro gas production and dry matter degradability of Acacia saligna leaves with inoculum from three ruminant species. Anim. Feed Sci. Tech. 123-124, 67-79.

Salem, A.Z.M., Olivares, M., López, S., González-Ronquillo, M., Rojo, R., Camacho, L.M., Cerrillo, S.M.A., Mejia, H.P., 2011a. Effect of natural extracts of Salix babylonica and Leucaena leucocephala on nutrient digestibility and growth performance of lambs. Anim. Feed Sci. Tech. 170, $27-34$.

Salem, A.Z.M., Hassan, A.A., Gado, H.M., Khalil, M.S., Simbaya, J., 2012. Effect of sun-drying and exogenous enzymes on nutrients intake and digestibility as well as nitrogen utilization in sheep fed Atriplex halimus foliages. Anim. Feed Sci. Tech. 171, 128-135.

Salem, A.Z.M., Robinson, P.H., El-Adawy, M.M., Hassan, A.A., 2007. In vitro fermentation and microbial protein synthesis of some browse tree leaves with or without addition of polyethylene glycol. Anim. Feed Sci. Tech. 138, 318-330.

Salem, A.Z.M., Robinson, P.H., Lopez, S., Gohar, Y.M., Rojo, R., Tinoco, J.L., 2010. Sensitivity of sheep intestinal lactic acid bacteria to secondary compounds extracted from Acacia saligna leaves. Anim. Feed Sci. Tech. 161, 85-93.

Salem, A.Z.M., Salem, M.Z.M., El-Adawy, M.M., Robinson, P.H., 2006. Nutritive evaluations of some browse tree foliages during the dry season: secondary compounds, feed intake and in vivo digestibility in sheep and goats. Anim. Feed Sci. Tech. 127, 251-267.

Salem, A.Z.M., Salem, M.Z.M., González-Ronquillo, M., Camacho, L.M., Cipriano, M., 2011b. Major chemical constituents of Leucaena leucocephala and Salix babylonica leaf extracts. J. Trop. Agric. 49 (1-2), 95-98.

SAS Institute, 2002. SAS User's Guide: Statistics. Ver 9.0. SAS Institute, Cary, NC, USA.

Sasaki, E., Shimada, T., Osawa, R., Nishitani, Y., Spring, S., Lang, E., 2005. Isolation of tannin-degrading bacteria isolated from feces of the Japanese large wood mouse, Apodemus speciosus, feeding on tannin-rich acorns. Syst. Appl. Microbiol. 28, 358-365.

Theodorou, M.K., Williams, B.A., Dhanoa, M.S., McAllan, A.B., France, J., 1994. A simple gas production method using a pressure transducer to determine the fermentation kinetics of ruminant feeds. Anim. Feed Sci. Tech. 48, 185-197.

Udén, P., Robinson, P.H., Mateos, G.G., Blank, R., 2011. Use of replicates in statistical analyses in papers submitted for publication in Animal Feed Science and Technology. Anim. Feed Sci. Tech. 171, 11-15.

Van Soest, P.J., 1994. Nutritional Ecology of the Ruminant. Cornell University Press, Ithaca, NY, USA.

Van Soest, P.J., Robertson, J.B., Lewis, B.A., 1991. Methods of dietary fiber, neutral detergent fiber and non-polysaccharides in relation to animal nutrition. J. Dairy Sci. 74, 3583-3597.

Xu, M., Rinker, M., McLeod, K.R., Harmon, D.L., 2010. Yucca schidigera extract decreases in vitro methane production in a variety of forages and diets. Anim. Feed Sci. Tech. 159, 18-26. 